\title{
PODSTAWOWE ASPEKTY WYKLADNI PRAWA W CHIŃSKIM PORZĄDKU PRAWNYM
}

Chinska sprawiedliwość jest squtuka, a nie nauką.

\section{Wprowadzenie}

Sztuka kaligrafii stanowi ważną część chińskiego dziedzictwa kultury, ukształtowała się ona ok. 2 tys. lat temu. Przy użyciu specjalnego pędzelka i papieru artysta maluje znaki, którym w zależności od zastosowanej techniki może nadawać rozmaita formę i kształt, wyrażając w ten sposób określone myśli, uczucia lub wartości estetyczne. Intencją artysty jest jednak nie tylko ekspresja wewnętrznych odczuć, lecz także próba odnalezienia harmonii ze społeczeństwem, przyrodą oraz całym uniwersum. Poznanie podstawowych reguł kaligraficznych umożliwia interpretacje pisma, zmierzając do zrekonstruowania myśli samego autora. W podobny sposób funkcjonuje działalność prawnicza, w ramach której dąży się do ustalenia wiążących konsekwencji prawnych stosowanej normy. Współczesny system prawny Chin nawiązuje w dużym stopniu do dorobku zachodniej tradycji prawnej, zachowując jednocześnie specyfikę własnej kultury. Wykorzystywane na Zachodzie reguły egzegezy nie moga być bezpośrednio stosowane w porządku chińskim ze względu na istniejące różnice językowe, wartości społeczne oraz uwarunkowania historyczne. Celem niniejszego artykułu jest próba określenia charakterystycznych cech wykładni prawa chińskiego, zarówno w ujęciu teoretycznym, jak i praktycznym.

\section{Perspektywa historyczna}

Określone warunki historyczno-kulturowe miały wpływ na to, że podstawowe zagadnienia prawne są odmiennie postrzegane w Chinach i państwach zachodnich. Starożytna polemika między konfucjanistami a legistami skupiała się na ocenie

\footnotetext{
ORCID: 0000-0002-2700-1578, DOI: 10.4467/23538724GS.21.003.14835

1 Y. Lin, My Country and My People, London 1936, s. 80, https://archive.org/details/MyCountryAndMyPeople1936 (dostęp: 5.06.2021).
} 
możliwości ustanowienia trwałego porządku społecznego za pomoca prawa, przy czym, o ile legiści uznawali prawo za konieczny instrument sprawowania efektywnych rządów, o tyle konfucjaniści większą wage przywiązywali do realizacji cnót ${ }^{2}$. Należy podkreślić, że logika nie była przedmiotem pogłębionych studiów w Państwie Środka, mimo że w czasach antycznych podejmowano pewne rozważania nad teorią języka (np. konfucjańska szkoła naprawy nazw, konwencjonalizm konfucjański, szkoła nazw, szkoła Późnych Moistów, chińska logika buddyjska³). Chińska kultura prawna ukształtowała się zupełnie inaczej niż rzymska - nie istniał tam wyraźny podział na prawo publiczne i prawo prywatne, normy zwyczajowe odgrywały ważniejszą rolę niż prawo pisane, nie powołano specjalnych szkół prawniczych ${ }^{4}$. Prawo pisane $(f a)$, które przypominało prawo stanowione w rozumieniu zachodnim, miało wyłącznie charakter karny i administracyjny, gwarantując przestrzeganie niepisanych norm zwyczajowych $(l i)^{5}$. Każda nowa dynastia cesarska uchwalała takie przepisy w formie zbiorów praw (kodeksów), które zachowywały obowiązujący charakter w czasie jej rządów ${ }^{6}$.

Wydawane zbiory praw były przedmiotem egzegezy kolejnych pokoleń prawników, którzy zajmowali się dopisywaniem odpowiednich adnotacji i komentarzy do ich treści. Studia dotyczące zbiorów praw (określane jako lüxue) są przykładem twórczej praktyki interpretacyjnej, umożliwiającej ujednolicenie stosowania prawa karnego pod rządami aktualnej dynastii. Lüxue miało przede wszystkim na celu wyjaśnienie intencji prawodawcy, używanej terminologii prawniczej oraz relacji między prawem stanowionym a precedensowym, co w rezultacie pozwalało dokonywać aplikacji przepisów do konkretnych przypadków ${ }^{7}$. Podstawowa tradycja studiowania kodeksów zachowywała przez wieki ciagłość, przypominając - w nawiązaniu do wizji Ronalda

2 M. Stępień, Spór konfucjanistón z legistami: w kregu chińskiej kultury prawnej, Kraków 2013, s. $235-236$.

3 S. Sikora, Dialog o biatym koniu (Bai Ma Lun) - metodologiczne problemy badań porównawcsych logiki chinskiej $i$ zachodniej, „Investigationes Linguisticae” 2006, vol. 14, s. 97-98, https://core.ac.uk/ download/pdf/144483181.pdf (dostęp: 5.06.2021).

4 D. Cao, Chinese Law: A Language Perspective, New York 2014, s. 3.

5 L. Zhang, Prawo porónnawcze w Chinach, „Forum Prawnicze” 2014, nr 5(25), s. 3. Fa określało przede wszystkim, jakie zachowania poddanych są zakazane, pełniło funkcję subsydiarną w stosunku do li.

6 I. Szpotakowski, Złota era w historii Chin - panowanie cesarza Taizonga z dynastii Tang [w:] Monarchia: idea, historia, perspektyny, red. K. Kofin, M. Kofin, Kraków 2018, s. 177. Jednym z najważniejszych pomników prawa w historii Chin był ogłoszony w 653 r. Kodeks Tang, który łączył koncepcje konfucjanizmu i legizmu.

7 Por. J. Zhang, The Tradition and Modern Transition of Chinese Law, Berlin - Heidelberg 2014, s. 297; D. Cao, Key Word in Chinese Law [w:] Images in Law, eds. A. Wagner, W. Pencak, Burlington 2006, s. 40; F. Constant, Circulation of Law and Jurisprudence of Korea and China: Homicide and the Notion of Requital of Life [w:] The Spirit of Korean Law: Korean Legal History in Context, ed. M. Kim, Leiden 2015, s. 56. 
Dworkina - zbiorowe pisanie jednej powieści (chain nove). Jak zauważyła Deborah Cao, ze względu na to, że późniejsze cesarskie kodeksy były wzorowane na Kodeksie Tang z VII w. n.e., oficjalna interpretacja prawnicza tej regulacji, w formie glos i komentarzy, zachowywała swój walor obowiązujący w przypadku uchwalania nowych kodeksów. Z tego powodu sformułowano później tezę, że w okresie cesarstwa nie istniała jurysprudencja, nie prowadzono systematycznych studiów nad prawem, a jedynie studiowano zbiory praw ${ }^{8}$. Wpływ na kształtowanie się wykładni prawa w Państwie Środka mogła mieć także specyfika języka chińskiego, z uwagi na jego konkretność, co prawdopodobnie nie sprzyjało tworzeniu abstrakcyjnych pojęć prawnych?

Wzrost wpływów państw europejskich w Chinach w XIX w. doprowadził do stopniowej modernizacji krajowego systemu prawa, zmierzającej w kierunku zaadaptowania zachodniej myśli prawniczej do warunków lokalnych. Uważa się, że to chiński polityk Lin Zexu z okresu dynastii Qing zainicjował w 1839 r. pierwsze tłumaczenia zagranicznych tekstów prawnych na język chiński. Mimo że przekłady, jakie pojawiły się w drugiej połowie XIX w. i do lat 20. XX w., były jeszcze pisane w klasycznym języku chińskim, to wprowadzenie zupełnie nowej terminologii prawniczej, nieznanej miejscowym intelektualistom, przyczyniło się do wykrystalizowania nowoczesnego, chińskiego języka prawnego ${ }^{10}$.

Komunistyczna Partia Chin w czasie wojny domowej w lutym 1949 r. wydała instrukcję, w której wyrażono krytykę ustawodawstwa Kuomintangu, a także Japonii, USA i państw europejskich. Proklamowanie Chińskiej Republiki Ludowej w 1949 r. zapoczątkowało rządy komunistyczne, co doprowadziło do zasadniczej reorientacji polityki prawa. Uchwalone wcześniej przez nacjonalistyczny rząd prawo zostało uchylone, jednocześnie podjęto działania na rzecz budowy socjalistycznego porządku prawnego według modelu radzieckiego. Prowadzono kampanię propagandowa skierowana przeciwko zachodniej myśli prawniczej, krytykowano m.in. Olivera W. Holmesa i Roscoe Pounda. Nowo uchwalona konstytucja z 1954 r. była wzorowana na Konstytucji ZSRR z 1936 r. ${ }^{11}$ Chińskie władze reprezentowały pragmatyczne podejście, zmierzając do selektywnego zaadaptowania radzieckich koncepcji

8 D. Cao, Key Word...

9 D. Cao, Chinese Law..., s. 4. Zgodnie z hipotezą Sapira-Whorfa różnice używanych struktur językowych mają wpływ na sposób myślenia o rzeczywistości.

10 D. Cao, Dillemas in Translating Legal Terms between Chinese and English [w:] Legal Translation: Current Issues and Challenges in Research, Methods and Applications, eds. I. Simonnæs, M. Kristiansen, Berlin 2019, s. 305-306; idem, Chinese Language in Law: Code Red, London 2018, s. 133. Wymiana kulturowa była obopólna, ponieważ przetłumaczenie praw cesarskich na języki europejskie pozwoliło poznać specyfikę kultury prawnej Chin w państwach zachodnich.

11 Zgodnie z art. 49 lit. c Konstytucji ZSRR z 1936 r. Prezydium Rady Najwyższej ZSRR miało prawo dokonywać wykładni obowiązujących ustaw ZSRR, natomiast art. 31 pkt 3 Konstytucji ChRL z 1954 r. zawierał analogiczną regulację, według której Stały Komitet OZPL ustalał wykładnię obowiązującego prawa. 
prawnych do aktualnych potrzeb ${ }^{12}$. W okresie rewolucji kulturowej (1966-1976) w kraju nie uchwalano nowych aktów prawnych ani nie nauczano prawa. Dopiero dojście do władzy Denga Xiaopinga zapoczątkowało proces nowoczesnej transformacji gospodarczej i legislacyjnej, który przeobraził współczesne Chiny. Dokonując modernizacji systemu prawa, odwołano się do rozwiązań przyjętych w państwach zachodnich, jednocześnie uwzględniając specyfikę chińskiej kultury prawnej.

\section{Ogólna charakterystyka wykładni prawa w Chinach}

W ogólnym ujęciu wykładnia prawa oznacza racjonalną działalność określonego podmiotu, która umożliwia odczytanie znaczenia tekstu prawnego. Metody i sposoby interpretacji zależą w znacznym stopniu od właściwości tekstu prawnego i języka, za pomocą którego tekst ten sformułowano. W literaturze przyjmuje się zasadniczo dwie podstawowe koncepcje zakresu wykładni prawa. W węższym sensie interpretacje przeprowadza się jedynie wówczas, gdy dostrzega się niejasności tekstu, wymagające wyjaśnienia istniejących różnic interpretacyjnych, natomiast w szerszym sensie interpretacji dokonuje się w każdym przypadku odczytywania tekstu, niezależnie od wiedzy i doświadczenia interpretatora, w celu jednoznacznego ustalenia obowiązujacej normy ${ }^{13}$.

Zgodnie z chińską teoria prawa konstytucyjnego i praktyką administracyjna przyjmuje się, że uprawnienie dokonywania formalnej wykładni przepisów ustawowych jest raczej funkcją władzy ustawodawczej, nie zaś sądowniczej ${ }^{14}$. Ze względu na moc wiążącą wykładni i podmiot podejmujący czynności interpretacyjne w systemie prawnym Chin można wyróżnić trzy rodzaje wykładni prawa: legislacyjna, sądową i administracyjną ${ }^{15}$. Do źródeł prawa w Chinach zalicza się konstytucję, ustawy (falii), przepisy administracyjne (xingzheng fagui), przepisy prawa miejscowego (difangxing fagui). Specyficznie chińskim źródłem prawa są także wykładnie (jieshi) przepisów, dokonywane przez uprawniony do tego organ. Uzupełnieniem działalności legislacyjnej jest praktyka orzecznicza Najwyższego Sądu Ludowego (NSL), który może wydawać opinie (yiijian) w zakresie stosowania przepisów w konkretnych przypadkach ${ }^{16}$. Zagadnienie wykładni prawa zostało częściowo uregulowane w kilku aktach prawnych: Konstytucji ChRL z dnia 4 grudnia

12 Por. X. Yu, Legal Pragmatism in the People's Republic of China, „Cornell Law Faculty Publications" 1989, s. 33-37, http://scholarship.law.cornell.edu/facpub/993 (dostęp: 31.05.2021).

13 Por. A. Barak, Purposive Interpretation in Law, Princeton 2005, s. 3-4; T. Chauvin, T. Stawecki, P. Winczorek, W stęp do prawoznawstwa, Warszawa 2014, s. 232-234.

14 S. Lubman, Introduction: The Future of Chinese Law, „The China Quarterly” 1995, no. 1, s. 4.

15 L. Wei, Judicial Interpretation in China, „Willamette Journal of International Law and Dispute Resolution" 1997, vol. 5, no. 1, s. 87.

16 J. Rowiński, W. Jakóbiec, System konstytucyjny Chińskiej Republiki Ludowej, Warszawa 2006, s. 63. 
1982 r., ustawie o organizacji sądów ludowych z dnia 1 lipca 1979 r. oraz ustawie o stanowieniu prawa z dnia 15 marca 2000 r.

1. Wykładnia legislacyjna

Wykładnia legislacyjna może być dokonywana przez Stały Komitet Ogólnochińskiego Zgromadzenia Przedstawicieli Ludowych, obejmuje ona interpretację przepisów konstytucji i ustaw obowiązujących w Chinach, Hongkongu i Makau ${ }^{17}$. Organ ten jest upoważniony do dokonania interpretacji w dwóch sytuacjach: gdy dokładne znaczenie przepisów prawa wymaga bliższego wyjaśnienia, jak również gdy ujawnią się nowe okoliczności po wejściu w życie przepisów, a jest konieczne wyjaśnienie podstaw ich stosowania (art. 45 ustawy z 2000 r. o stanowieniu prawa). Należy podkreślić, że Ogólnochińskie Zgromadzenie Przedstawicieli Ludowych (OZPL), czyli chiński parlament, nie może wydawać aktów interpretacyjnych konstytucji i ustaw, ma natomiast do tego prawo jego właściwy organ - Stały Komitet OZPL. Wydawane wykładnie przepisów Stałego Komitetu OZPL mają moc wiążącą równą aktom prawnym, których dotyczą (art. 47 ustawy z 2000 r. o stanowieniu prawa).

Stały Komitet OZPL korzysta z wykładni legislacyjnej raczej powściągliwie, interpretacje są wydawane ad hoc, zdecydowanie częściej odnoszą się do treści ustaw niż konstytucji. Dotychczas dokonał łącznie 16 interpretacji, które obejmowały: 4 interpretacje ustawy Prawo podstawowe Specjalnego Regionu Administracyjnego Hongkongu z 4 kwietnia 1990 r., 1 interpretację ustawy Prawo podstawowe Specjalnego Regionu Administracyjnego Makau z dnia 31 marca 1993 r., 9 interpretacji Prawa karnego oraz 2 interpretacje ustawy o obywatelstwie z dnia 10 września 1980 r. ${ }^{18}$ Ustawa zasadnicza nie przewiduje ograniczeń dotyczących treści i zakresu nowelizacji lub wykładni jej postanowień. Wykładnia konstytucji przez Stały Komitet OZPL mogłaby teoretycznie służyć większej elastyczności i łatwiejszemu usuwaniu pojawiających się luk prawnych, bez potrzeby nowelizacji konstytucji ${ }^{19}$. Naturalnie, nie można zaakceptować takiej sytuacji, gdy pod pozorem formalnej wykładni przepisu prawnego miałaby de facto miejsce zmiana konstytucji. W tym kontekście godna uwagi jest inicjatywa profesora Lianga Huixinga z 2012 r., członka Stałego Komitetu OZPL, który skierował do parlamentu projekt ustawy o procedurze wykładni konstytucji, opracowany przez specjalistów ze Szkoły Prawa Uniwersytetu Renmin w Pekinie ${ }^{20}$. Zestawienie wydanych interpretacji pokazuje,

17 Artykuł 67 pkt 1 i 4 Konstytucji Chińskiej Republiki Ludowej z dnia 4 grudnia 1982 r. określa, że Stały Komitet OZPL dokonuje wykładni konstytucji i nadzoruje jej wykonanie, jak również dokonuje wykładni innych aktów prawnych.

18 Y. Lin, Constitutional evolution through legislation: The quiet transformation of China's Constitution, „International Journal of Constitutional Law” 2015, vol. 13, no. 1, s. 84.

19 Ibidem, s. 81. Konstytucja ChRL z 1982 r. była nowelizowana pięciokrotnie (1988 r., 1993 r., 1999 r., 2004 r., 2018 r.).

20 Ibidem, s. 84. 
że dotychczasowa praktyka Stałego Komitetu OZPL koncentruje się głównie na wyjaśnianiu znaczenia pojęć z zakresu prawa karnego (np. dokonano wiążącej interpretacji pojeć́: „,sprzeniewierzenie środków publicznych na własny użytek”, „zorganizowana grupa przestępcza”, ,karta kredytowa”).

Rada Państwowa, Centralna Komisja Wojskowa, Najwyższy Sąd Ludowy (NSL), Najwyższa Prokuratura Ludowa (NPL), każda specjalna komisja OZPL, stałe komitety terenowych zgromadzeń przedstawicieli ludowych na szczeblu prowincji, regionów autonomicznych i miast wydzielonych mają prawo kierować do Stałego Komitetu OZPL wnioski o dokonanie wykładni legislacyjnej ${ }^{21}$. Wykładnia zagadnień dotyczących czynności sądowych lub prokuratorskich jest przeprowadzana przez NSL lub NPL. W przypadku rozbieżności między interpretacją NSL a interpretacją NPL sa one przedstawiane Stałemu Komitetowi OZPL w celu ujednolicenia wykładni prawa zgodnie z pkt 2 Rezolucji Stałego Komitetu OZPL z dnia 10 czerwca 1981 r. w sprawie udoskonalenia wykładni prawa. W pewnym sensie uprawnienia interpretacyjne Stałego Komitetu OZPL przypominaja, właściwą dla państw europejskich, kontrolę sprawowaną przez trybunał konstytucyjny. Wydawane interpretacje są jednak pisane zwięźle i nie zawierają uzasadnienia. Wykładnię zagadnień niezwiązanych z czynnościami sądowymi lub prokuratorskimi zapewnia Rada Państwowa i właściwe departamenty. Jeżeli przepisy prawa miejscowego wymagają wyjaśnienia lub zmiany, stałe komitety terenowych zgromadzeń przedstawicieli ludowych na szczeblu prowincji, regionów autonomicznych i miast wydzielonych moga dokonywać ich interpretacji lub zmiany (pkt 3 i 4 wspomnianej Rezolucji).

Artykuł 67 pkt 3 Konstytucji ChRL przewiduje ponadto uprawnienie Stałego Komitetu OZPL do częściowego wprowadzania, w okresie między sesjami OZPL, poprawek i zmian do uchwalonych przez Zgromadzenie ustaw, o ile nie prowadzi to do zmiany podstawowych zasad tych aktów prawnych. Jak wynika z pkt 1 Rezolucji Stałego Komitetu OZPL z 1981 r., jeżeli obowiązujące przepisy ustaw i dekretów wymagaja wyjaśnienia lub zmiany, Stały Komitet OZPL ma prawo dokonywać ich interpretacji lub uchwalić zmianę przepisów. Nie jest zrozumiałe, czy taka wykładnia przepisu ustawy ww. organu ogranicza się tylko do wyjaśnienia znaczenia przepisu prawnego, czy może łącznie obejmować wyjaśnienie i zmianę przepisu, a więc czy wykładnia ma charakter odtwórczy, czy też twórczy. Konstytucja odróżnia od siebie uchwalanie poprawek i zmian do ustaw (art. 67 pkt 3) od wykładni ustaw (art. 67 pkt 4), ale jednocześnie nie delimituje zakresów obu wskazanych czynności ${ }^{22}$.

21 Art. 46 ustawy o stanowieniu prawa z dnia 15 marca 2000 r. Ustawa ta ma w kontekście problematyki wykładni prawa w chińskim porządku prawnym dość ograniczone znaczenie, ponieważ reguluje wyłącznie kwestie dokonywania interpretacji przez Stały Komitet OZPL.

${ }^{22}$ H. Fu, Guide to Legislative Interpretation in China (Prof Hualing Fu), 2017, HKU Legal Scholarship Blog, http://researchblog.law.hku.hk/2017/07/guide-to-legislative-interpretation-in.html (dostęp: 1.06.2021). 
2. Wykładnia sądowa

Prawo dokonywania wykładni sądowej przysługuje NSL, który odgrywa w chińskim porządku prawnym szczególną rolę interpretacyjną. Władzę sądowniczą sprawują NSL, lokalne sądy ludowe na różnych szczeblach, sądy wojskowe i sądy specjalne (art. 124 Konstytucji ChRL). Praktyka orzecznicza sądów ludowych nie opiera się na precedensach, ale na indywidualnym badaniu okoliczności każdej konkretnej sprawy. Sprawne funkcjonowanie krajowego orzecznictwa wymaga stosowania nie tylko jasnych, zrozumiałych przepisów prawnych, lecz także jednolitych zasad ich interpretacji. Zgodnie z konstytucją NSL odpowiada za swoją działalność przed OZPL i Stałym Komitetem OZPL (art. 133 zdanie 1 Konstytucji ChRL). W myśl art. 18 ustawy o organizacji sądów ludowych z dnia 1 lipca 1979 r. organ ten może dokonywać wykładni sądowej określonych zagadnień, które dotyczą stosowania prawa w praktyce orzeczniczej. Wykładnia sądowa ma powszechną moc wiążąca, powinna być formułowana zgodnie z właściwym ustawodawstwem i duchem prawa oraz rzeczywistymi potrzebami praktyki orzeczniczej, na co wskazują art. 3 i 5 wytycznych Najwyższego Sądu Ludowego z dnia 9 marca 2007 r. w sprawie praktyki wykładni sądowej. Interpretacja NSL ma bardzo szeroki zakres, ponieważ jest wiążąca dla wszystkich sądów orzekających na terytorium całego kraju.

Jak zauważa Yulin Fu, w niektórych przypadkach wydawane interpretacje NSL będą miały charakter abstrakcyjny, bez związku z rozstrzyganiem konkretnej sprawy sądowej (wykładnia normatywna), natomiast w innych będą odnosiły się do indywidualnej sprawy rozpatrywanej przed sądem (wykładnia indywidualna) ${ }^{23}$. Wykładnia normatywna ma na celu zapewnić ogólne zasady, które w określonym zakresie umożliwiają doprecyzowanie, wyjaśnienie i uzupełnienie działalności ustawodawcy, co w rezultacie pozwala na ujednolicenie interpretacji przepisów prawa krajowego $^{24}$. Ponadto NSL ma prawo ogłaszać wiążące interpretacje w czterech różnych formach: wykładni prawa (jieshi), postanowienia (guiding), odpowiedzi (pifü) i decyzji (juéding). Wykładnia prawa obejmuje interpretacje sądowe dotyczące szczególnego stosowania określonego przepisu w praktyce orzeczniczej lub w pewnych kategoriach spraw. Za pomoca postanowień formułuje się standardy lub opinie, które są niezbędne w praktyce orzeczniczej. Gdy sądy wyższej instancji lub sądy wojskowe zwracają się z prośbą o przedstawienie interpretacji stosowania przepisu w konkretnym przypadku, taka interpretacja jest wydawana w formie odpowiedzi. Zmiana lub anulowanie dotychczasowej interpretacji sa natomiast dokonywane w formie decyzji (art. 6 wytycznych NSL z 2007 r.).

Działalność orzecznicza NSL cechuje znaczny aktywizm sędziowski, który dotyczy interpretacji konkretnych regulacji prawnych. Dotychczasowe interpretacje

\footnotetext{
23 Y. Fu, The Chinese Supreme People's Court in Transition [w:] Supreme Courts in Transition in China and the West Adjudication at the Service of Public Goals, eds. C.H. van Rhee, Y. Fu, Cham 2017, s. 25.

${ }^{24}$ Ibidem, s. 28.
} 
były często wydawane niedługo po wejściu w życiu określonej ustawy, a czasami zawierały szczegółowe wytyczne na temat właściwego rozumienia jej poszczególnych przepisów ${ }^{25}$. W latach 1979-2004 NSL wydał łącznie 2889 interpretacji sądowych, spośród których 2577 zachowało moc wiążąca, 309 zostało uchylonych, a tylko 3 zostały zmienione ${ }^{26}$. W świetle opisywanej praktyki orzeczniczej pojawił się problem rozstrzygania wątpliwości interpretacyjnych samodzielnie przez inne sądy ludowe. Zgodnie z wytycznymi z 1997 r. NSL jednoznacznie stwierdził, że powszechnie wiazżąca wykładnia sądowa może być dokonywana jedynie przez tę instytucję sądową, a sądy orzekające niższej instancji są nią związane. Wydaje się, że faktyczne egzekwowanie przepisów ustawowych, opartych na ogólnych zasadach i nieprecyzyjnych terminach, byłoby praktycznie niemożliwie, gdyby nie dotychczasowa działalność interpretacyjna NSL. Mimo posiadania szerokiego zakresu uprawnień w tym zakresie, NSL nie jest upoważniony do dokonywania wykładni przepisów prawa administracyjnego, przepisów wydawanych przez rząd oraz przepisów prawa miejscowego ${ }^{27}$.

3. Wykładnia administracyjna

Rada Państwowa ChRL (Centralny Rząd Ludowy) stanowi najwyższy organ wykonawczy i administracyjny, posiada prawo ustanawiania właściwych środków administracyjnych oraz wydawania przepisów administracyjnych, decyzji i zarządzeń, zgodnie z konstytucją i ustawami (art. 89 pkt 1 Konstytucji ChRL). Organowi temu przysługuje także prawo dokonywania wykładni administracyjnej poprzez wydawanie specjalnych regulacji w zakresie interpretacji przepisów administracyjnych. Przyznanie szerokich kompetencji Radzie Państwowej powoduje, że stanowi ona de facto najsilniejszą instytucję prawodawczą we współczesnych Chinach, uchwalając corocznie bardzo dużo przepisów administracyjnych - ponad 70\% ustaw rozpatrywanych przez OZPL lub Stały Komitet OZPL inicjuje i często opracowuje Rada Państwowa, ma ona także znaczny wpływ na interpretację przepisów prawnych ${ }^{28}$.

Reguły procedury ustanawiania przepisów administracyjnych z dnia 16 listopada 2001 r. (dalej: Reguły) określaja podstawowe czynności, jakie powinny być podejmowane przy interpretacji przepisów administracyjnych. Rada Państwowa jest upoważniona do wykładni przepisów administracyjnych, gdy dokładne znaczenie przepisów prawa wymaga bliższego wyjaśnienia, jak również gdy ujawnią się nowe okoliczności po wejściu przepisów w życie, a jest konieczne sprecyzowanie podstaw ich stosowania. W tym przypadku powtórzono treść art. 45 ustawy

25 J. Chen, Chinese Law: Context and Transformation, Leiden - Boston 2008, s. 200.

26 Ibidem, s. 173.

27 Ibidem, s. 201-202.

28 Ibidem, s. 183-184. Autor wskazuje, że w latach 1979-2005 łącznie uchwalono w Chinach 762 ustaw i 3985 przepisów administracyjnych (czyli w podanym okresie wydano pięciokrotnie więcej przepisów administracyjnych niż ustaw). 
o stanowieniu prawa, który dotyczy uprawnień Stałego Komitetu OZPL w zakresie wykładni konstytucji i ustaw. Departament Spraw Legislacyjnych Rady Państwowej opracowuje interpretacje przepisów administracyjnych, a następnie przedstawia je do zatwierdzenia Radzie Państwowej. W myśl art. 31 Reguł interpretacje przepisów administracyjnych mają moc wiążącą równą przepisom administracyjnym, których dotyczą. Poszczególne departamenty Rady Państwowej i rządy ludowe prowincji, regionów autonomicznych i miast wydzielonych bezpośrednio podległych rządowi centralnemu mogą zwrócić się do Rady Państwowej o dokonanie interpretacji przepisów administracyjnych (art. 32 Reguł).

W 2004 r. NSL wydał dokument dotyczący stosowania przepisów i zasad departamentalnych w działalności orzeczniczej w sprawach administracyjnych. W założeniu ma pomóc sądom ludowym rozwiązywać ewentualne sprzeczności między przepisami prawa miejscowego a wydawanymi na szczeblu centralnym zasadami departamentalnymi. Mimo że wytyczne opisane w tym dokumencie nie mają charakteru wiążącej wykładni sądowej NSL, to sądy niższej instancji powinny uwzględniać jego treść w praktyce orzeczniczejej ${ }^{29}$.

\section{Wykładnia prawa w Chinach - ujęcie teoretyczne}

Okres rządów Mao Zedonga nie sprzyjał rozwojowi w Chinach refleksji teoretycznej na temat wykładni prawa, dlatego też pierwsze rozważania poświęcone współczesnej teorii prawa podjęto dopiero w latach 80. XX w. W ciagu następnych kilkunastu lat chińscy uczeni zaczęli zmieniać dotychczasowe podejście, stopniowo odchodząc od poglądów marksistowskich właściwych tzw. konstytucjonalizmowi socjalistycznemu na rzecz zachodniej idei rządów prawa i demokratyzacji. Na uwage zasługuje zwrot historyczny w kierunku okcydentalizacji teorii prawa w Chinach, co miało również miejsce w Państwie Środka na początku XX w. W chińskiej nauce prawa konstytucyjnego dostrzegalne jest swoiste napięcie między stanowiskiem idealistycznym a realistycznym, przypominające dychotomię law in books oraz law in action $^{30}$. Watpliwości nadal budzi zagadnienie związane z podstawową rolą konstytucji w krajowym porządku prawnym, charakterem norm konstytucyjnych czy zakresem wykładni konstytucji itp.

${ }^{29}$ Ibidem, s. 191. Do podstawowych zasad określonych w tym dokumencie, które należy stosować, zalicza się następujące: 1. reguła prawna, która wynika z przepisów o wyższej mocy prawnej lub które zostały zatwierdzone przez organ wyższego stopnia, ma pierwszeństwo; 2. reguła prawna dotycząca zagadnień handlu zagranicznego i inwestycji zagranicznych, wydana przez organy na szczeblu centralnym, ma pierwszeństwo; 3. reguła prawna dotycząca ściśle spraw lokalnych ma pierwszeństwo; 4. w razie wątpliwości właściwy sąd przekaże sprawę NSL w celu rozstrzygnięcia.

30 F. Lin, Idealism and Realism in Chinese Constitutional [w:] Constitutionalism and the Rule of Law: Bridging Idealism and Realism, eds. M. Adams, A. Meuwese, E.H. Ballin, Cambridge 2017, s. 316. 
Postanowienia konstytucji uchwalane w państwach rządzonych przez partie komunistyczne miały charakter polityczny, faktycznie zaś nie były realizowane. W warunkach gospodarki wolnorynkowej konieczne stało się wypracowanie nowego paradygmatu stosowania chińskiej konstytucji. Jednym z bardziej interesujących przykładów była sprawa Qi Yuling z 2001 r., w przypadku której NSL podjął próbę wprowadzenia w Chinach sądowej kontroli konstytucyjności (analogicznie jak w amerykańskiej sprawie Marbury v. Madison z 1803 r.) ${ }^{31}$. Problematyka interpretacji obowiązującej ustawy zasadniczej stała się przedmiotem analizy różnych autorów, co pozwoliło na ukształtowanie się dwóch zasadniczych teorii wykładni konstytucji - teorii normatywnej oraz teorii interpretacyjnej.

Pierwsza z nich została opisana w 2001 r. przez prof. Lina Laifana, według którego głównym przedmiotem badań prawa konstytucyjnego powinny być normy konstytucyjne wynikające z tekstu konstytucji, innych źródeł prawa konstytucyjnego i orzecznictwa ${ }^{32}$. Jego zdaniem ustawę zasadniczą należy badać na trzech różnych poziomach, przy uwzględnieniu metod podstawowych, metod ogólnych oraz metod szczegółowych. W pierwszej kolejności wykorzystuje się metody podstawowe, poszukując takich rozwiązań, które pozwalają odpowiednio usystematyzować wartości konstytucyjne, zarazem dostosowując je do realiów społeczno-politycznych XXI w., co można uzyskać np. poprzez łączenie teorii z praktyka, dokonanie analizy podstawowej, historycznej, porównawczej i systematycznej. Metody ogólne odwołują się do wiadomości z zakresu filozofii prawa, jurysprudencji, socjologii, polityki. Metody specyficzne odnoszą się z kolei do wypracowania konkretnych umiejętności, które są związane z aplikacją metod podstawowych i ogólnych w badaniach nad konstytucją ${ }^{33}$.

Drugie stanowisko, związane z teorią interpretacyjna, jest reprezentowane przez Hana Dayuana. Autor ten uważa, że chińskie prawo konstytucyjne ma silne związki z polityka, co negatywnie wpływa na stosowanie postanowień konstytucji. Proponuje on posługiwać się metodami hermeneutycznymi, które umożliwią w jak najszerszym zakresie pogodzenie norm konstytucyjnych z rzeczywistością polityczna. Naturalnie, w celu takiego ujednolicenia nie jest jednak dopuszczalne wykraczanie poza granice aksjologii konstytucji, chyba że zostanie przyjęta odpowiednia zmiana ustawy zasadniczej. Konstytucja jest bowiem oparta na pewnych wartościach, które powinny być każdorazowo realizowane w celu utrzymania porządku konstytucyjnego w Chinach ${ }^{34}$. Ustawa zasadnicza określa podstawowe zasady ustroju politycznego, społecznego i gospodarczego, tym samym wyznaczając ustawodawcy istotne

31 Ibidem, s. 295. Kilka lat później NSL zmienił jednak swoje stanowisko w tej kwestii.

32 Ibidem, s. 317-318.

33 J. Mo, G. Zhai, Continuous Growth in Reform and Opening-up: Three Decades of Development of Constitutional Law Studies in China [w:] Constitutional Development in China, 1982-2012, eds. L. Li, J. Mo, G. Zhai, Singapore 2020, s. 55. W swoich rozważaniach autor ten nawiązuje do znanej koncepcji Karla Loewensteina, który wyróżniał konstytucje normatywne, nominalne i semantyczne.

34 F. Lin, Idealism and Realism..., s. 318-319. 
kierunki interpretacji przepisów prawa krajowego. Hermeneutyka konstytucyjna koncentruje się na analizie języka ustawy zasadniczej, przy czym traktując język jako medium ludzkiego doświadczenia, stara się dostosować sposób rozumienia pojęć z przeszłości do aktualnych warunków społecznych. Wykładnia prawa powinna zatem także służyć przekładaniu dawnych pojęć na takie, które zachowają społeczny sens, ale już w nowych okolicznościach ${ }^{35}$.

Odwołanie się przez krajowego ustawodawcę do zachodnich wzorców prawno-ustrojowych nie oznacza, że rozumie się je w taki sam sposób jak na Zachodzie. W mentalności mieszkańców Dalekiego Wschodu podstawowe aspekty życia społecznego sa regulowane przez normy zwyczajowe $(l i)$, wpisane w naturalny porzadek rzeczywistości, zaś ustawy wydawane przez rządzących w danym państwie ( $f a$ ) są tworzone tylko przez ludzi. W kręgu kultury zachodniej obie te sfery określa się jednak mianem prawa (prawo naturalne, prawo stanowione), mimo że odnoszą do odmiennych elementów rzeczywistości. Na uwagę zasługuje inicjatywa OZPL, które w 1999 r. przyjęło nowelizację Konstytucji ChRL, wyraźnie nawiązując w treści art. 5 do idei rządów prawa $(f a z h i)^{36}$.

Jedną z podstawowych zasad współczesnego prawa karnego jest zasada określoności czynu zabronionego w treści ustawy (nullum crimen sine lege), co znaczy, że ustawodawca powinien dokładnie sprecyzować podstawowe znamiona takiego czynu w treści ustawy. W chińskim porządku prawnym nie jest jednak konieczne, aby zachowanie było uznane za bezprawne expressis verbis przez ustawodawcę, ponieważ dopuszcza się w tym zakresie stosowanie analogii. Wystarczające jest podobieństwo danego czynu do znamion innych penalizowanych zachowań. Podobna sytuacja ma miejsce w prawie cywilnym i gospodarczym, w ramach którego używa się słowa deng (,,i tak dalej”), mającego wskazywać na katalog otwarty, często stosuje się je też pod koniec wyliczania czynności zabronionych ${ }^{37}$.

35 G. Leyh, Toward a Constitutional Hermeneutics, „American Journal of Political Science” 1988, vol. 32, no. 2, s. 374. Zdaniem Hana Dayuana należy stopniowo odchodzić od tradycyjnych kategorii pojęciowych, utrwalonych w prawie konstytucyjnym, na rzecz ustanowienia własnego systemu słów, specyficznych dla chińskiej kultury prawnej.

36 Artykuł 5 Konstytucji ChRL stanowi: „Chińska Republika Ludowa jest socjalistycznym państwem prawnym realizującym rządy prawa”. W języku chińskim fą̧bi oznacza dwa różne pojęcia, ponieważ jest ono rozumiane jako system prawny lub jako rządy prawa. W konstytucji użyto go w tym drugim znaczeniu. Idea rządów prawa jest przypisywana chińskiej szkole legistów, działającej w Okresie Wiosen i Jesieni (ok. 770 r. p.n.e. - 476 r. p.n.e.) i Okresie Walczących Królestw (475 r. p.n.e. -221 r. p.n.e.).

37 C. Ross, L. Ross, Sources of Systemic Vagueness and Ambiguous Authority in Chinese Statutory Language [w:] The Limits of the Rule of Law in China, eds. K.G. Turner, J.V. Feinerman, R.K. Guy, Seattle 2000, s. 255. W polskim ustawodawstwie używa się w tym celu zwrotu „w szczególności”, np. w prawie cywilnym. Należy podkreślić, że w prawie karnym obowiązuje zakaz wykładni rozszerzającej i stosowania analogii na niekorzyść sprawcy przestępstwa. 
Według Penga Juna Lianga wykładnia przepisów prawa w Chinach może obecnie przybierać kilka różnych form: wykładni językowej, wykładni logicznej, kontekstualnej i historycznej ${ }^{38}$.

Struktura języka chińskiego jest oparta na wykorzystaniu określonych znaków (np. piktogramów, ideogramów, znaków złożonych), nie zaś na użyciu liter mogących tworzyć wyrazy lub sylaby, tak jak to ma miejsce w językach państw zachodnich. Jak podkreśla Deborah Cao, w przypadku języków indoeuropejskich, takich jak angielski, oznaczenia językowe zapewniają określone wskazówki interpretacyjne, pomocne przy ustaleniu znaczenia tekstu. W języku chińskim takie wskazówki gramatyczne nie sa zwykle dostępne, podstawowe reguły interpretacji wynikają z kontekstu użycia znaków, w tym przypadku większą rolę odgrywają reguły semantyczne niż syntaktyczne i gramatyczne ${ }^{39}$. Przepisy prawne uchwalane w Państwie Środka charakteryzuje nadmierna ogólność, niejasność oraz występowanie nieprecyzyjnych terminów. Ocenia się, że organy administracyjne preferują właśnie bardziej ogólne regulacje, umożliwiające elastyczność i pozostawiające im swobodę działania według własnego uznania. Podobne rozwiązania są stosowane w odniesieniu do umów gospodarczych, które często zawierają ogólne i nieklarowne wyrażenia językowe, dzięki czemu strony umowy mogą wypracować bardziej szczegółowe rozwiązania dopiero w przyszłości, w zależności od potrzeby ${ }^{40}$.

Wykładnia językowa jest uważana za podstawowy sposób interpretacji przepisów prawa, polega ona na ustaleniu znaczenia wyrażeń tekstu prawnego przy wykorzystaniu reguł semantycznych i syntaktycznych języka prawnego. Z uwagi na posługiwanie się językiem naturalnym przy opracowaniu tekstów prawnych nie jest możliwe uniknięcie ich wieloznaczności (open texture of law), a język chiński ma pod tym względem podobne właściwości jak języki indoeuropejskie. W języku chińskim pojęcie „zobowiązanie” może być wyrażone za pomocą ośmiu różnych zwrotów, przy czym w aktach prawnych często używa się zwrotów bixu (interpretacja mocna obowiązku: na pewno, koniecznie, z pewnością musi) oraz ying (interpretacja słaba obowiązku: odpowiedzieć, zgodzić się, powinien). W zachodniej kulturze prawnej zobowiązania egzekwuje się wówczas, gdy są one zabezpieczone sankcją (interpretacja mocna obowiązku), natomiast w Państwie Środka takie zobowiązania moga być uregulowane zarówno $\mathrm{w}$ formie interpretacji mocnej, jak i w formie interpretacji słabej (nawet w obrębie tej samej ustawy, np. prawo małżeńskie z 1980 r.). Tradycja konfucjańska miała wpływ na to, że zobowiązania moralne (li) mają obecnie w Chinach charakter instytucjonalny, chociaż stosuje się je w różny sposób, w zależności od konkretnych okoliczności ${ }^{41}$.

38 Hong Kong's Constitutional Debate: Conflict Over Interpretation, eds. J.M.M. Chan, H.L. Fu, Y. Ghai, Hong Kong 2000, s. 380.

39 D. Cao, Chinese Law..., s. 98.

40 Ibidem, s. 95-96.

41 Por. C. Ross, L. Ross, Sources of Systemic Vagueness..., s. 228-230. 
Analiza chińskich tekstów prawnych pozwala wyróżnić pięć podstawowych predykatów modalnych: bixu, yingdang/ying, zdanie bez użycia czasownika modalnego, keyi, bude. Zwrot bixu odpowiada angielskiemu must lub shall, wyraża nakaz zachowania się w określony sposób lub zobowiązanie do podjęcia pewnej czynności ${ }^{42}$. Posłużono się nim w art. 4 ustawy w sprawie umów gospodarczych w obrocie międzynarodowym z dnia 21 marca 1985 r.: „Zawierając umowę, strony mają obowiązek [bixu] przestrzegać prawa Chińskiej Republiki Ludowej i nie mogą szkodzić interesowi publicznemu Chińskiej Republiki Ludowej”. Użycie yingdang/ying jest podobne do angielskiego shall, stosuje się je podobnie jak bixu w celu wyrażenia nakazu, np. art. 16 tej ustawy stanowi: „Umowa staje się prawnie wiążąca z chwila jej zawarcia, zgodnie z prawem. Strony powinny [yingdang] wykonać swoje obowiązki wynikające z umowy". Pojęcie yingdang pojawia się w obowiązujących przepisach częściej niż bixu, np. w Ogólnych zasadach prawa cywilnego z 1986 r. lub prawie karnym z $1979 \mathrm{r}^{43}$

Ustawodawca konstruuje także przepisy, za pomoca których wyraża obowiązek, ale nie posługuje się w tym celu żadnym predykatem modalnym, zamiast tego określając skutki prawne danej czynności. Brak użycia predykatu modalnego nie znaczy, że norma prawna traci swój imperatywny charakter ${ }^{44}$. Przykładem jest art. 9 ustawy w sprawie umów gospodarczych w obrocie międzynarodowym: „Umowy niezgodne z prawem lub interesem publicznym Chińskiej Republiki Ludowej są nieważne [wuxiao]". Z kolei zwrot keyi wyraża możliwość swobodnego działania stron lub skorzystania z przyznanego uprawnienia i pojawia się np. w art. 24 wspomnianej ustawy: „Zakres działania siły wyższej może [keyi] być określony w umowie” ${ }^{45}$. W przypadku posłużenia się zwrotem bude wskazuje się na obowiązek nieczynienia czegoś, czyli należy w przewidzianej sytuacji powstrzymać się od działania ${ }^{46}$. Przykładem jego użycia jest art. 16 tej ustawy: „Żadna ze stron nie może [bude] jednostronnie zmieniać ani odstapić od umowy".

W procesie interpretacji przepisów prawnych niezbędne jest posługiwanie się zasadami poprawnego rozumowania w taki sposób, aby decyzje interpretacyjne były każdorazowo wydawane po przeprowadzeniu wszechstronnej analizy przepisów, zarówno pod kątem formalnym, jak i merytorycznym. W chińskich tekstach prawnych często używa się nieprecyzyjnych zwrotów łączących (spójników logicznych), co może mieć wpływ na klarowność i sposób rozumienia prawa. Jeżeli nie występują

42 D. Cao, Chinese Law..., s. 56. Można stwierdzić, że zwrot bixu jest prawdopodobnie stosowany w celu rekonstrukcji norm prawnych, które są określane w polskiej literaturze prawniczej jako bezwzględnie wiążące (iuris cogentis).

43 Ibidem, s. 65.

${ }^{44}$ Ibidem, s. 57-58.

45 Zwrot keyi jest prawdopodobnie stosowany w celu zrekonstruowania norm prawnych, które są określane w polskiej literaturze prawniczej jako względnie wiążące (iuris dispositivi).

46 D. Cao, Chinese Law..., s. 58. 
takie zwroty łączące, kluczową rolę przy interpretacji tekstu odgrywa kontekst, w jakim użyto poszczególnych wyrażeń. Anglojęzyczne spójniki and i or (tzw. coordinating conjunctions) są stosowane do tłumaczenia różnych chińskich wyrażeń językowych, np. he, gen, bing (qie), haishi i huozhe ${ }^{47}$.

Między obu wskazanymi kategoriami zachodzą jednak istotne różnice. Za pomocą spójników and i or można łączyć rzeczowniki, frazy rzeczownikowe, czasowniki, frazy czasownikowe, przymiotniki, frazy przymiotnikowe, przysłówki, frazy przysłówkowe, przyimki, frazy przyimkowe oraz zdania. Chińskie wyrażenia maja natomiast węższe zastosowanie, np. bing służy do łączenia fraz czasownikowych, he łączy rzeczowniki, frazy rzeczownikowe i rzadziej czasowniki, buoz̧he łączy frazy czasownikowe i rzadziej frazy rzeczownikowe. Angielskie i chińskie spójniki nie zawsze jednak mają to samo znaczenie. Ponadto należy zwrócić uwagę na to, że spójniki zdań równorzędnych nie są wcale powszechnie stosowane w języku chińskim ${ }^{48}$.

\section{Podsumowanie}

Zagadnienie wykładni prawa w Chinach ukształtowało się odmiennie niż w państwach należących do kręgu zachodniej kultury prawnej. U podstaw myślenia na temat prawa leży filozofia konfucjańska, która przywiązuje większą wagę do pielęgnowania ludzkich cnót, przypisując mniejsze znaczenie prawu stanowionemu. Interpretacja tekstów prawnych jest oparta na szczególnych cechach chińskiego języka pisanego, w którym dla właściwego zrozumienia przepisu powinno się wziąć pod uwagę kontekst wypowiedzi. Posługiwanie się specyficznymi regułami egzegezy może świadczyć o bardziej pragmatycznym podejściu, większej elastyczności oraz konieczności dostosowania prawa do rzeczywistości społecznej. W tym właśnie duchu można rozumieć słowa: „Chiński sędzia nie może traktować prawa jako abstrakcyjnego bytu, ale raczej jako elastyczną jakość, która powinna osobiście dotyczyć Pułkownika Huanga czy Majora Li. Dlatego każde prawo, które nie jest wystarczająco osobiste, by odnieść się do osobowości Pułkownika Huanga czy Majora Li, jest nieludzkie, a zatem wcale nie jest prawem. Chińska sprawiedliwość jest sztuką, a nie nauką"49.

${ }^{47} \mathrm{Na}$ gruncie logiki formalnej przyjmuje się, że spójnik and reprezentuje koniunkcję $(\mathrm{p} \wedge \mathrm{q})$, natomiast w przypadku alternatywy spójnik or może być użyty jako funktor alternatywy zwykłej (inclusive or - p V q; wyraża to zwrot either $x$ or $y$, or both $x$ and $y$ ) lub funktor alternatywy wykluczającej (exclusive or $-\mathrm{p} \underline{\mathrm{v}} \mathrm{q}$; wyraża to zwrot either $x$ or $y$, but not both).

48 C. Ross, L. Ross, Sources of Systemic Vagueness..., s. 240-242.

49 Y. Lin, My Country and My People, London 1936, s. 80, cyt. za: R. Nisbett, Geografia myślenia. Dlaczego ludzie Wschodu i Zachodu myśla inaczej, tłum. E. Wojtych, Sopot 2003, s. 242. 


\section{Literatura}

Barak A., Purposive Interpretation in Law, Princeton 2005.

Cao D., Chinese Language in Law: Code Red, London 2018.

Cao D., Chinese Law: A Language Perspective, New York 2014.

Cao D., Dillemas in Translating Legal Terms between Chinese and English [w:] Legal Translation: Current Issues and Challenges in Research, Methods and Applications, eds. I. Simonnæs, M. Kristiansen, Berlin 2019.

Cao D., Key Word in Chinese Law [w:] Images in Law, eds. A. Wagner, W. Pencak, Burlington 2006.

Hong Kong's Constitutional Debate: Conflict Over Interpretation, eds. J.M.M. Chan, H.L. Fu, Y. Ghai, Hong Kong 2000.

Chauvin T., Stawecki T., Winczorek P., W stęp do prawoznawstwa, Warszawa 2014.

Chen J., Chinese Law: Context and Transformation, Leiden - Boston 2008.

Constant F., Circulation of Law and Jurisprudence of Korea and China: Homicide and the Notion of Requital of Life [w:] The Spirit of Korean Law: Korean Legal History in Context, ed. M. Kim, Leiden 2015.

Fu Y., The Chinese Supreme People's Court in Transition [w:] Supreme Courts in Transition in China and the West Adjudication at the Service of Public Goals, eds. C.H. van Rhee, Y. Fu, Cham - Switzerland 2017.

HKU Legal Scholarship Blog, http://researchblog.law.hku.hk/2017/07/guide-to-legislative-interpretation-in.html (dostęp: 1.06.2021).

Leyh G., Toward a Constitutional Hermeneutics, „American Journal of Political Science” 1988, vol. 32(2).

Lin F., Idealism and Realism in Chinese Constitutional [w:] Constitutionalism and the Rule of Law: Bridging Idealism and Realism, eds. M. Adams, A. Meuwese, E.H. Ballin, Cambridge 2017.

Lin Y., Constitutional evolution through legislation: The quiet transformation of China's Constitution, „International Journal of Constitutional Law" 2015, vol. 13(1).

Lin Y., My Country and My People, London 1936, https://archive.org/details/MyCountryAndMyPeople1936 (dostęp: 5.06.2021).

Lubman S., Introduction: The Future of Chinese Law, „The China Quarterly” 1995, no. 1.

Mo J., Zhai G., Continuous Growth in Reform and Opening-up: Three Decades of Development of Constitutional Law Studies in China [w:] Constitutional Development in China, 1982-2012, eds. L. Li, J. Mo, G. Zhai, Singapur 2020.

Nisbett R., Geografia myślenia. Dlaczego ludżie Wschodu i Zachodu myśla inaczej, tłum. E. Wojtych, Sopot 2003.

Ross C., Ross L., Sources of Systemic Vagueness and Ambiguous Authority in Chinese Statutory Language [w:] The Limits of the Rule of Law in China, eds. K.G. Turner, J.V. Feinerman, R.K. Guy, Washington 2000.

Rowiński J., Jakóbiec W., System konstytucyjny Chińskiej Republiki Ludowej, Warszawa 2006.

Sikora S., Dialog o bialym koniu (Bai Ma Lun) - metodologiczne problemy badań porównawcsych logiki chińskiej $i$ zachodniej, „Investigationes Linguisticae” 2006, vol. 14.

Stępień M., Spór konfucjanistón z legistami: w kregu chinskiej kultury prawnej, Kraków 2013.

Szpotakowski I., Złota era w historii Chin - panowanie cesarza Taizonga z dynastii Tang [w:] Monarchia: idea, historia, perspektywy, eds. K. Kofin, M. Kofin, Kraków 2018.

Wei L., Judicial Interpretation in China, „Willamette Journal of International Law and Dispute Resolution" 1997, vol. 5, no. 1.

Yu X., Legal Pragmatism in the People's Republic of China, „Cornell Law Faculty Publications” 1989, http://scholarship.law.cornell.edu/facpub/993 (dostęp: 31.05.2021).

Zhang J., The Tradition and Modern Transition of Chinese Law, Berlin - Heidelberg 2014.

Zhang L., Prawo porównawcze w Chinach, „Forum Prawnicze” 2014, nr 5(25). 


\section{SUMMARY}

\section{BASIC ASPECTS OF LEGAL INTERPRETATION IN THE CHINESE LEGAL ORDER}

Chinese legal culture was shaped in a different way than Western legal culture, these differences have a significant impact on the rule of law, fundamental rights and democracy in contemporary China. Legal interpretation is one of the formal sources of law in China. The authority to interpret legislation is usually characterized as a legislative rather than a judicial function. The Standing Committee of the National People's Congress (NPC), the State Council and the Supreme People's Court have a special role in interpretive activities. Chinese legal interpretation includes semantic rules, the cultural and linguistic context of law, basic constitutional principles, the hierarchy of sources of law and reasoning by analogy. 